\title{
A NETWORK APPROACH FOR MOVING FROM PLANNING TO IMPLEMENTATION IN CLIMATE CHANGE ADAPTATION: EVIDENCE FROM SOUTHERN MEXICO
}

\author{
Elisa Calliaria,b,e, Melania Michetti ${ }^{\mathrm{b}}$, Luca Farniac, Emiliano Ramieri ${ }^{\mathrm{d}}$ \\ ${ }^{a}$ University College London, ${ }^{b}$ Euro-Mediterranean Center on Climate Change, ${ }^{c}$ Fondazione Eni \\ Enrico Mattei, d Thetis S.P.A., ${ }^{\mathrm{e}}$ Ca' Foscari University of Venice
}

\begin{abstract}
Collaboration barriers have been reported among the most frequent institutional constraints to adaptation. Yet, the growing literature on the topic has been largely descriptive and little attention has been placed on how to transform barriers into enablers for action. By taking a fragile socioecological lagoon system in Southern Mexico as a case study, the paper applies a social network analytical approach to: i) reveal the actual web of connections tying stakeholders through local governance arrangements; ii) identify shortcomings in multi-actor collaboration networks; and iii) propose ways to tackle them so that the full potential of adaptation can be exploited. The paper employs a mixed-method approach combining both a quantitative and qualitative Social Network Analysis (SNA). The quantitative SNA is used to assess the quality and strength of relationships among formal public organisations working on climate adaptation and disaster risk reduction in the site. The qualitative SNA is employed to both assess linking ties between formal organizations and local coastal communities potentially targeted with adaptation interventions, and bonding ties connecting community members. The approach proves to be useful to map the relational architecture of the system of interest and to reveal network characteristics that are important for collective action including: network fragmentation in subgroups; density of relations; centralization around a few actors. The actual topology of the network, as revealed, can then be compared with what is required for achieving societally desired adaptation outcomes and for identifying agents that can promote change. The paper acknowledges that a social analytical approach might be limited in unveiling the interests and motives behind actors' participation in the network, and that the latter ultimately determine actors' contribution in defining and enacting a joint solution for a common problem. However, the mixed-methods approach presented in this paper allows for gaining first insights on the way a mismatch between formal and informal institutions might drive socioecological systems towards inadequate adaptation outcomes.
\end{abstract}

Keywords: adaptation barriers; social network analysis; collaborative governance; institutions 


\section{Highlights:}

- Collaboration barriers are analysed as constraints to effective climate adaptation

- The paper presents a mixed-method approach based on Social Network Analysis

- The method is tested in a fragile coastal socio-ecosystem is Southern Mexico

- The method reveals the complex socio-institutional interplay driving adaptation outcomes 


\section{INTRODUCTION}

In the past decade the scientific, policy and practice communities have increasingly looked at adaptation as a fundamental and unavoidable strategy to respond to the risks posed by climate change. At the international level, the Paris Agreement (PA) (UNFCCC 2015) placed adaptation on pair with mitigation, sanctioning the long awaited "political parity" under the Convention of these two synergetic pillars of climate action. On the operational side, Article 7 of the PA calls all Parties to "engage in adaptation planning processes and the implementation of actions, including the development or enhancement of relevant plans, policies and/or contributions". Although slowly, adaptation is currently progressing from a phase of awareness to the predisposition of actual responses (Mimura et al. 2014). A number of actions are being undertaken in both developed and developing countries in climate sensitive sectors like agriculture, water management, coastal defence, public health, and disaster risk management. Progress has also been registered in the development of adaptation strategies and plans at the national, local and community levels as well as in the private sector.

Yet, moving from planning to implementation remains a challenge. This is due to a number of wider practical, socioeconomic and institutional factors that can actually constrain the realization of desirable adaptation actions (Chambwera et al. 2014) and thus lead to an adaptation gap (UNEP 2014). The IPCC refers to these factors or processes as implementation constraints. Common barriers in social systems comprise the lack of resources (finance, technology and knowledge) and institutional characteristics hampering action (Klein et al. 2014). Institutional constraints are indeed the most frequently reported in the literature (Biesbroek et al. 2013). They include: i) failure in elevating adaptation as a political priority; ii) consideration of adaptation as an isolated task of a sector/governance unit (the so called "silo problem"); iii) lack of vertical and horizontal coordination between different administrative levels and between formal agencies and private stakeholders (Mimura et al. 2014). In addition, the feasibility and acceptability of adaptation measures - also determined by the realignments of power and knowledge they entail (Eriksen and Lind 2009, Nightingale 2017)- feature as important political barriers both in developed and developing countries.

Constraints make it harder to adapt, but can in principle be circumvented, lowered or removed (Moser and Ekstrom 2010). They thus conceptually differ from adaptation limits, as the latter imply that no adaptive options exist to secure actors or systems' objectives (Dow et al. 2013). This distinction, however, is more difficult to be kept when adopting a dynamic perspective as, with time, constraints can either turn into or drive a system to an adaptation limit (Barnett et al. 2015). It is therefore essential to tackle implementation constraints if the full potential of adaptation measures is to be exploited. Yet, how to do it has been little investigated so far. The growing literature on the constraints to adaptation has been largely descriptive and few analysis lead to the identification of entry points and strategies for intervention (Eisenack et al. 2014). 
The paper address this research need by focusing on collaboration barriers as a particularly frequent constraint to adaptation (Oberlack 2017) and by applying a network approach to diagnose them and propose solutions. Collaborative governance has been long-advocated for dealing with complex problems like climate adaptation. It draws attentions not only to the individual characteristics and capacity of actors, but also to the way they are connected to one other and how they collaborate towards the attainment of a common objective. Yet, these governance processes are often difficult to achieve in practice. Moreover, collaboration per se cannot guarantee that the intended outcomes will be delivered. It is thus important to give concurrent consideration to three elements to understand if and in which direction adaptation will unfold: i) who the actors are; ii) the networks through which they collaborate; and iii) how the structure of the "collaborative network" relates to their abilities to address the problems (Bodin 2017).

We employ Social Network Analysis (SNA) for disentangling these aspects and for moving from adaptation planning to implementation. The benefits of employing SNA are multiple. As a mapping tool, SNA provides an x-ray of social interactions and is thus able to depict the actual governance structure supporting adaptation in the system of interest. Yet SNA has also a powerful diagnostic potential, as it allows for i) identifying the nodes (individuals, groups, organisations) that play a central role in implementing adaptation together with those that are instead isolated or missing, and for ii) assessing the nature of ties linking or excluding them. This way it is possible to spot were the problematic ties are as well as to identify those nodes that can act as enablers for change. With the aim of fostering multi-level institutional collaboration and the agency of local community in implementing adaptation, strategies for fixing or enhancing the institutional network can thus be designed.

We test the diagnostic potential of SNA on the governance arrangements supporting adaptation and disaster risk reduction interventions in a fragile coastal socio-ecological system in the north-west coast of the Mexican State of Tabasco. The Carmen-Pajonal-Machona (C-P-M) lagoon system is chosen for the complex interplay of physical, environmental and socio-economic factors, which makes it particularly vulnerable to the impacts of climate change. On top of the current and expected climatic stressors, the site is undergoing serious erosion, flooding, contamination and salinization problems that are leading to irreversible losses in terms of land, freshwater resources and biodiversity, and threatening the traditional livelihood base of local farmers and anglers' communities. As adaptation measures have only recently started to be carried out on the ground, investigating the collaborative governance system that can support and sustain them becomes particularly relevant. This means understanding what the actual connections among institutional and community stakeholders are, and how these networks can be enhanced to realise adaptation potential and minimise the risk of irreversible losses. A focus on collaboration is further justified by the institutional response elaborated by the government of Tabasco, and consisting in the creation of the Inter-Secretarial Commission on Climate Change of the state of Tabasco (TABASCO 2013) as a way to foster a cross-sectoral approach in planning and executing climate policies in the state. 
The paper first discusses the importance of social networks for collaborative governance in climate change adaptation. It then introduces the case study and the methodology employed for assessing the nature and strength of connection among formal organizations dealing with climate change adaptation/disaster risk reduction (CCA/DRR) in the site. A mixed-method approach is employed for assessing i) the ties connecting formal organisations (quantitative SNA) and ii) the connection between formal organizations and local coastal communities potentially targeted with adaptation interventions (qualitative SNA). The paper concludes with a discussion on the applicability of SNA in the detection of collaboration constraints to adaptation and elaboration of strategies to overcome them.

\section{THEORETICAL FRAMEWORK: INSTITUTIONAL NETWORKS FOR CLIMATE CHANGE ADAPTATION}

Institutions, as systems of established and prevalent social rules that structure social interactions (Hodgson 2006), have been long acknowledged as crucial determinant of adaptive capacity (Smit and Pilifosova 2001, Engle 2011). A distinction is usually made between formal institutions, comprising tangible procedures, laws and regulations, and tacit informal institutions, including values, norms, traditions, codes, and conducts (Ostrom 1990). Much of the adaptation discourse so far has focused on formal public institutions (Klein et al 2014), although increasing evidence has been provided of their informal counterpart playing a role in driving adaptation processes. In particular, social capital, social networks, values, perceptions, interests, customs, and traditions have been recognised as important elements affecting the capacity of communities to adapt (Adger et al. 2007).

There is less agreement on the institutional attributes that actually matter for adaptation (Oberlack 2017). Attempts were made in identifying some general characteristics institutions should have to stimulate the capacity of societies to adapt. For instance, Gupta (2010) cites variety, i.e. the attitude to involve different perspectives, actors and solutions; learning capacity; room for autonomous change; leadership; resources; and fair governance. Grothmann et al. (2013) add the psychological dimension to list by including "adaptation motivation" and "adaptation beliefs". Other commonly mentioned institutional traits encompass inclusiveness, flexibility, risk tolerance, legitimacy, accountability, creativity, transparency, and autonomy (Koontz et al. 2015). With a similar normative standpoint, Dixit, Mcgray, Gonzales, \& Desmond (2012) identify a set of functions -assessment, prioritization, coordination, information management, and climate risk management- formal institutions should perform and that are critical for adaptation.

Institutions provide the "rules of the game" (North 1990) but how the latter will be played (and what will be achieved) eventually depends on the actors involved and their relational patterns. Organisations are primary actors in enacting societal responses to climate change (Berkhout 2012). They represent a special type of institutions characterised by i) boundaries which distinguish members by non-members, ii) principles designing who is in charge, and iii) chains of command 
assigning responsibilities within the organisation (Hodgson 2006). Examples of organisations include households, firms, civil society organisations (CSOs), public sector agencies and local governments.

Beyond attributes and capacity, collaboration among them is essential for pooling together the different competences and scales needed for adaptation in complex socio-ecological systems and for avoiding silos approaches eventually leading to partial or even maladaptive outcomes. Calls for multi-actor collaboration have been extensively made in discussing governance approaches for complex, wicked problems. For instance, the concepts of polycentric (Ostrom 2010), multi-level (Corfee-Morlot et al. 2009) and network governance (Luthe et al. 2012) stress the importance of a diversified set of actors in solving collective action problems. On a similar vein, adaptive comanagement combines the attention to learning processes which is proper to adaptive management with the focus, derived from the co-management tradition, on collaboration among different stakeholders operating at different levels through social networks (Folke et al. 2005).

Social networks have been found to facilitate collaboration among different stakeholders by supporting the generation and diffusion of knowledge, information and resources across the system; fostering engagement and commitment to common rules; and smoothening the resolution of conflicts (Bodin and Crona 2009). Yet, collaboration itself cannot guarantee that societal objectives will be reached (Bodin et al. 2016). Collaborative arrangements might miss out important actors having a special interest or ability to address the problem at hand. At the same time, the structure of the network through which they collaborate might enable or restrict their behaviour (Wasserman and Faust 1994) and thus affect intended outcomes.

It is therefore imperative to investigate who the actors are and how they are tied together. Actors can be linked to one another in different ways. A classical distinction has been made between horizontal networks that "bring together agents of equivalent status and power" and vertical networks implying an "asymmetric relations of hierarchy and dependence" (Putnam 1993). More recently, the terms bonding and bridging ties have been employed to designate social networks between homogenous and heterogeneous groups respectively (Putnam 2000). A sub-category of bridging ties is constituted by linking ties (Woolcock 2001), as connections which vertically transcend group boundaries and imply relative differences in power. Examples of linking ties include connections between social classes, or between local communities and formal institutions. With specific reference to adaptation, bonding ties based on family and kinship can be an important asset to cope with the impacts of extremes (Adger 2003), as extensively shown by DRR literature (Hawkins and Maurer 2010). At the same time, they can also be detrimental in the long run as they atomise society in small closed groups, undercut social interaction and trust and thus undermine collective action (Pelling 1998). Bridging ties have proved to play an important role for innovation and promoting transformative adaptation actions (Dowd et al. 2014) as they allow for accessing resources and opportunities in a different group. Linking ties can facilitate the transfer of resources along the social hierarchy but they are typically shaped as top-down relations and thus challenging 
the maintenance of social trust and cooperation (Pelling and High 2005). It is thus important to maintain a dynamic interplay of bonding, bridging and linking ties to both support resilience building and the diversity which is needed to adapt (Newman and Dale 2005).

All these aspects (i.e. actors, network nature and structure) can be usefully investigated through SNA. SNA has been widely used in social sciences, from psychology to economics (Borgatti et al. 2009), and has proved to be suitable for thinking about institutional connections in a strategic way (Holland 2007). It has increasingly been employed to examine the role of societal relationships in disaster contexts (e.g., Jones \& Faas, 2017), natural resource management (Prell et al. 2009) and promising applications have started to emerge in the study of local climate change adaptation. It was used to identify how adaptation-related information is shared at the community level (Rotberg 2013, Cunningham et al. 2016); to retrospectively assess the interactions between organizations elaborating (Ingold et al. 2010) or implementing adaptation measures (Jaja et al. 2016); to identify key actors in adaptation decision making at the national (Bowen et al. 2014) and local scales (VarelaOrtega et al. 2016); and to explore collaboration patterns of formal entities working on agriculture and rural development (Schmitt et al. 2013) and water management (Azhoni et al. 2017). Yet, these studies have mostly focused on homogenous groups -either local communities or groups of formal institutions- and have largely neglected the investigation of vertical, hierarchical ties between the two. Exploring the full scope of ties in social systems - i.e. bonding, bridging and linking - can instead importantly shed light on the direction and speed at which adaptation unfolds (Pelling and High 2005).

\section{CASE STUDY}

The C-P-M lagoon system is a low-depth ( $0.9 \mathrm{~m}$ on average) coastal wetland of about $190 \mathrm{~km}^{2}$, which is separated from the ocean by a fragile sand bar (Figure 1). It consists of two lagoons (Carmen on the west and Machona on the east) which are connected by the Pajonal narrower water body. The area hosts important mangrove habitats, that have been highly impacted in the last decades, due to land-use changes (mainly into agriculture land and grassland for animal breeding), illegal cut for wood consumption, and erosion of the mangrove banks (Buenfil Friedman 2009).

The C-P-M system administratively belongs to the Chontalpa sub-region and, in particular, to the municipalities of Cárdenas, Comalcalco and Paraíso. It hosts medium to small human communities, strongly relying on the lagoon system services for their subsistence. Their main productive activities are agriculture, livestock, fishery (in particular of oysters), and aquaculture. Production is strongly characterised by the presence of a cooperative system. Communities are organized in the form of "ejidos", civil corporations endowed with legal personality, and assembly of partners and representative authorities. The Chontalpa Plan, implemented in the area since 1965, has sought to increase agricultural (rice, cocoa, corn, plantain and citrus) and cattle production in the area to 
stimulate socio-economic development. Yet, its results have been mixed so far (Pinkus Rendón and Contreras-Sánchez 2013) and important pockets of poverty persist in the municipalities surrounding the lagoons. For instance, in the municipality of Cardenas $20,38 \%$ and $44,91 \%$ of the population lives in situations of extreme and moderated poverty respectively (CONEVAL 2010).

These communities have suffered several political, socio-economic, and environmental impacts throughout their history, both due to contingent and structural transformations occurring in the state of Tabasco. Three historical events have importantly contributed to shape the socio-ecological vulnerability patterns of the site (Vázquez 2017): i) the transformation of Tabasco in a bananaproducing state in the 1920s and 1930s; ii) the massive deforestation process carried out in the 1960s and 1970s to promote agricultural and livestock farming; iii) the boom of oil extraction in the state since the 1970s. The increasing reliance on the banana trade since the 1920s transformed Tabasco into an immense banana-producing state, with monoculture being encouraged by converting traditional intercropping and by massively deforesting the southern part of the country (Ridgeway 2001). This resulted in soil depletion and the heavy use of pesticides, with harmful effects on the local population and the environment (Gliessman 2014). The expansion of the farming and livestock frontiers in the 1960 further contributed to deforestation, bringing down the total surface covered by forests from $49 \%$ in 1940 to $8 \%$ in 1990 (Tuleda 1990). Oil extraction and distribution through the state-owned company Petróleos Mexicanos (PEMEX) have further severely impacted the local socioecosystem by strongly distorting the original biological equilibrium of the lagoon (Tudela 1989); displacing (by expropriation) peasants from their lands; polluting soils, waterways, and resources; and forcing rural communities to abandon their primary activities (Negrete Salas 1984, Beltrán 1988). 


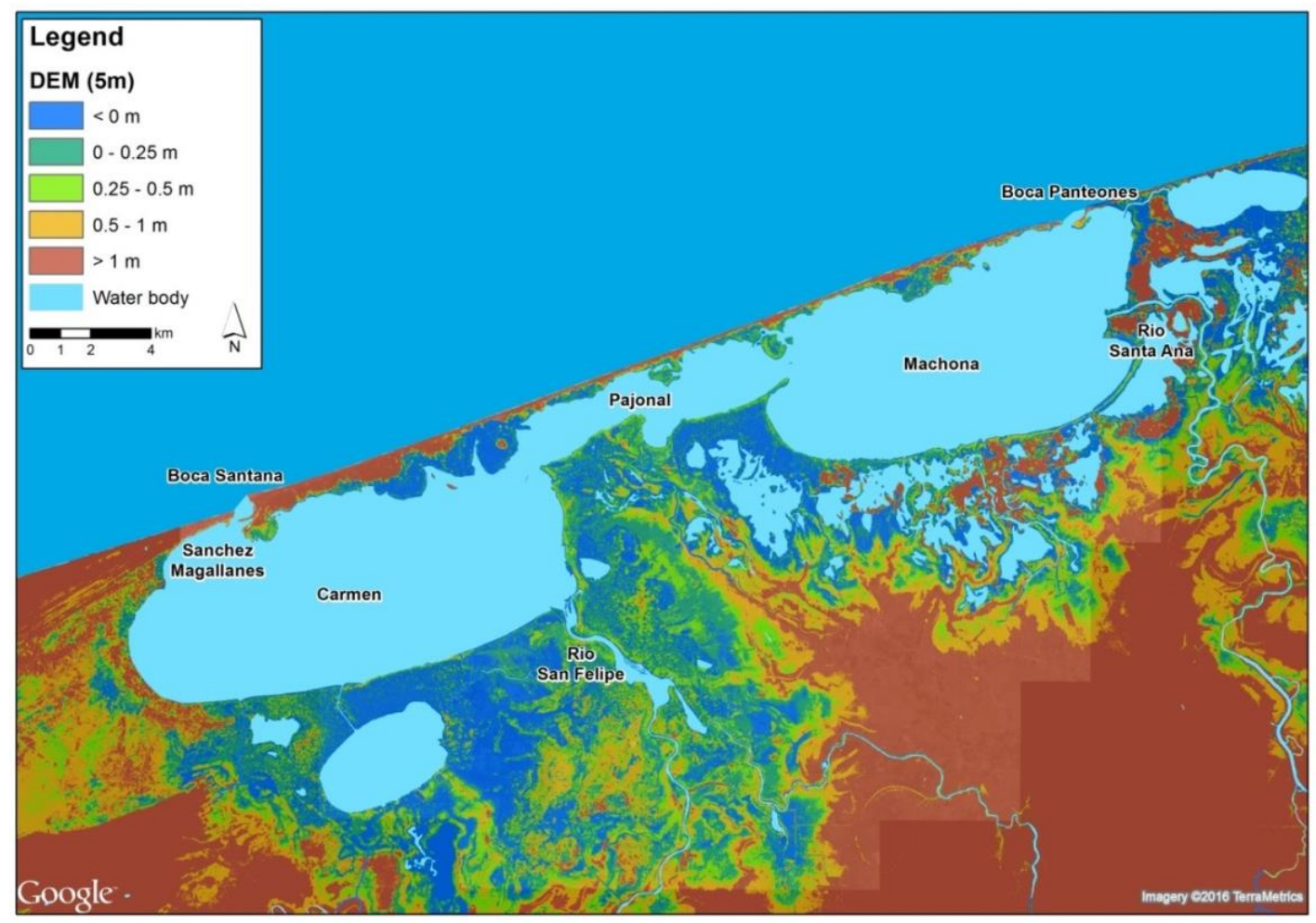

Figure 1: The Carmen-Pajonal-Machona lagoon system. The map shows the land elevation of the area around C-P-M lagoon system (source of DEM data: LIDAR 5 m INEGI 2012).

A comprehensive study recently undertaken in the C-P-M site highlighted a number of current (Ramieri et al. 2015) and expected (Ramieri et. al 2015) challenges posed by climate change to the socio-ecosystem. The vulnerability of the littoral bar is expected to increase due to the erosion of local beach and dune systems induced by sea level rise (SLR) and extreme wind events. This will result in an increased risk of flooding associated with storm surges, as well as a higher risk of rupture of the littoral on the long term (2100), with particular concern for the eastern portion of the C-P-M system. Frequency and intensity of river flooding events is also expected to increase due to change in precipitation patterns. SLR will also increase saltwater intrusion and thus the surface affected by soil salinization. Part of the mangrove system might be able to adapt through vertical accretion, if sufficient amount of sediments will be available, and inland migration, depending on the availability of suitable habitats and absence of anthropic obstacles. In any case, mangroves will still be affected by increased erosion of the lagoon banks and by anthropic pressures like land use change. Other potential climate change impacts include: diffusion of vector-borne diseases due to new conditions (e.g. higher temperature) and favourable habitats (small water bodies created by mangrove erosion/loss), introduction of alien species in the lagoon system; decreased agricultural production resulting from higher mean temperatures, increased water and soil salinization, and floods; salinization of small domestic wells, increase risk of damage to the road network and other infrastructures.

Despite these criticalities, also recognised by the Climate Change Action Programme of the State of Tabasco (Tabasco 2011), adaptation projects and wider initiatives in the lagoon system have 
traditionally been scant. A possible reason for that, among others, is the conflicting relationship between local institutions and coastal communities, where the former think that communities are "difficult" to work with and the latter have the sense to be forgotten by the local institutions ${ }^{1}$. More recently, community-based adaptation (CBA) interventions have started to be planned and implemented in the site with the external support of the federal government and backed by international donors. The C-P-M lagoon featured as a pilot site in the World Bank funded project "Adaptation of coastal wetlands in the Gulf of Mexico (2011-2015)" implemented by the National Institute of Ecology and Climate Change (INECC) and Instituto Mexicano de Tecnología del Agua (IMTA) ${ }^{2}$, and comprising activities such as reforestation, capacity development with communities, and establishment of early warning systems. Additionally, the C-P-M system has been mapped within the recently created Atlas of Risk (Atlas de riesgos del Estado de Tabasco) ${ }^{3}$, which is a digital GIS tool supporting decision-making by displaying municipal thematic maps on vulnerable areas, as well as other civil protection and integrated risk management related actions.

\section{Methods AND MATERials}

The study adopted a mixed-method approach, combining both a quantitative and a qualitative SNA to assess the strength and nature of links among i) formal organizations engaged in DRR/CCA in the site; ii) community members; and iii) formal organization and community members. Building on Agrawal (2010) we refer to these aspects as institutional articulation, community articulation and institutional access respectively. The mixed-method approach was designed to account for the high illiteracy rates characterising the case study area and which would make it difficult to fully engage communities in the intensive data collection process required for a quantitative SNA.

\subsection{ASSESSING INSTITUTIONAL ARTICULATION}

\subsubsection{Data collection strategies}

As a first step, the boundaries of the system of interest were set by identifying institutional actors (potentially) engaged in CCA/DRR and NRM activities in the case study area. Attention was drawn to three types of organisations (Bhagavan and Virgin 2004): i) government entities, like ministerial departments, policy-making and regulatory authorities, regulatory authorities, and specialised

\footnotetext{
${ }^{1}$ Personal communication with the authors during a field visit in June 2015.

2 The present research is part of the "Design of adaptation measures to reduce vulnerability of the pilot site CarmenPajonal-Machona Lagoon System, Tabasco, to the impacts from climate change and anthropogenic activities" run by Thetis, CMCC and Coastal Environment and part of the mentioned "Adaptation of coastal wetlands in the Gulf of Mexico" project.

${ }^{3}$ Available at: http://www.atlasnacionalderiesgos.gob.mx/AtlasEstatales/?\&NOM_ENT=Tabasco\&CVE_ENT=2
} 
agencies; ii) knowledge-generating institutions, including universities and research institutes; and iii) civil society organisations working on environmental issues.

Governmental entities were determined through an extensive review of national and local legislative and planning instruments supporting adaptation, disaster risk reduction and natural resource management in Tabasco so to identify those mandated to operate in the lagoon system. Knowledgegenerating institutions and civil society organisations were identified through online searching and interviews with local experts. As Table 1 shows, the mapping process brought to the identification of 34 actors that were invited to a workshop in Villahermosa in June 2015 (for information on the workshop design see Giannini et al.(2017)). Each actor represented a specific institution, except for CONAGUA in which case representatives of two specific departments (water planning and wetland) were invited. This was in line with the wider focus of the study on water-related threats in the lagoon system. Among them, 21 took part in the workshop and were surveyed through a dedicated questionnaire.

Table 1: List of institutions mapped and surveyed. Acronyms: L=Local; S= State; N=National; I=International

\begin{tabular}{|c|c|c|c|c|}
\hline Sector & Scale & Institution & Acronym & \begin{tabular}{|l|}
$\mathbf{N}$ \\
surveyed
\end{tabular} \\
\hline & $\mathrm{L}$ & Municipality of Cárdenas & & \\
\hline & \multirow{9}{*}{$S$} & State Forestry Commission & COMESFOR & \\
\hline & & $\begin{array}{l}\text { Secretariat of Energy, Natural } \\
\text { Resources and Environmental } \\
\text { protection }\end{array}$ & SERNAPAM & 1 \\
\hline & & $\begin{array}{l}\text { Secretariat of Agriculture, } \\
\text { Livestock and fisheries } \\
\text { development }\end{array}$ & SEDAFOP & \\
\hline & & $\begin{array}{l}\text { Secretariat of Economic } \\
\text { development and tourism }\end{array}$ & SDET & \\
\hline & & $\begin{array}{l}\text { Coordinación General de } \\
\text { Desarrollo Regional y Proyectos } \\
\text { Estratégico }\end{array}$ & CGDRPE & 1 \\
\hline & & Civil Protection (Cardenas) & & 1 \\
\hline & & Secretariat of Health & Ssalud & 1 \\
\hline & & Port Authority of Dos bocas & API dos bocas & 1 \\
\hline & & Secretariat of Public Education & SEP & 1 \\
\hline & \multirow{2}{*}{$\mathrm{N}$} & $\begin{array}{l}\text { National Water Commission } \\
\text { (water planning) }\end{array}$ & CONAGUA & 1 \\
\hline & & $\begin{array}{l}\text { National Water Commission } \\
\text { (wetlands) }\end{array}$ & CONAGUA & 1 \\
\hline
\end{tabular}




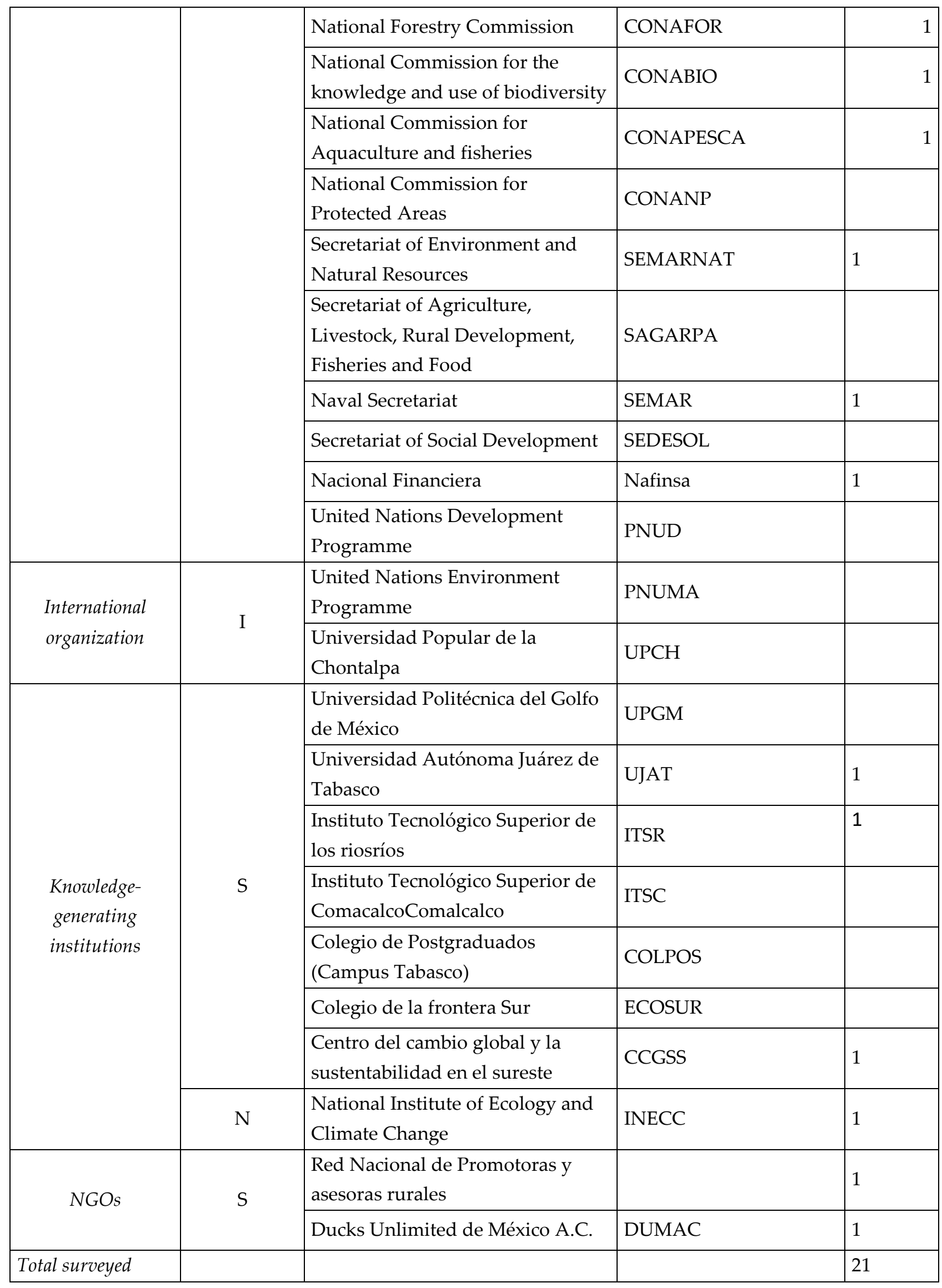


The questionnaire comprised two parts. The first part, made of six questions, aimed at collecting information on the organisation and the work undertaken in the C-P-M lagoon systems (human resources available, thematic focus and activities carried out). Respondents were also asked to indicate the main thematic focus of their work, choosing among CCA, DRR, NRM and socioeconomic local development. The second part of the questionnaire assessed the nature and strength of inter-organizational links through a matrix. As recognition methods are generally better than recall methods when capturing social ties (Marsden 1990), a pre-compiled list of organisations was presented to respondents. As a way to double check the completeness of the list, respondents were encouraged to add actors which they deemed important but had been left out. Only in one case (SEMARNAT) new actors were identified and included in the SNA. Through the matrix, respondents evaluated the nature of their connection with other organizations (if existent) in terms of: i) information exchange; ii) coordination; iii) collaboration. In this context, collaboration was defined as the implementation of joint projects or initiatives. These three categories of ties are understood as implying increasing degrees of strength in the relation amongst actors. In the case of the new actors identified by SEMARNAT, the relationship was qualified as "coordination" as representing the median value. When no connection with the listed institutions existed, respondents could have specified possible reasons (e.g., lack of knowledge about the actor's work or interest; failed attempts to communicate with the actor; lack of resources for collaboration; no apparent reasons for collaboration). Finally, respondents were asked to provide additional information about the CSOs they worked with. This follow-up question was included as CSOs are scant in Tabasco and have limited organizational capacity, making their ex ante identification challenging.

\subsubsection{Data Analysis}

Data was analysed and visualised through the igraph package in R (Csardi and Nepusz 2006). Two networks and related statistics were produced, accordingly with the indication made by surveyed organizations of the dominant thematic focus of their work (DRR/CCA or NRM-not shown here).

Following Bodin and Crona (2009), we considered and computed a set of network structural characteristics that relates to governance processes and outcomes: network density, cohesion and centralization as well as two measures of actor centrality (degree and betweeness). Network density is calculated as the number of existing ties divided by the number of possible ties. In general, the higher the network density the higher the potential for collective action (Marwell et al. 1988). However, too high density can also be detrimental as it can lead to homogenisation in terms of information and knowledge shared in the network and thus reduce its adaptive capacity (Bodin and Norberg 2005). Network cohesion refers to the presence of distinguishable subgroups or communities. Their presence can pose challenges to collective action if subgroups work in isolation. At the same time, these subgroups can embed information or knowledge, which is important for dealing with the complexity of the problem at hand. We identify subgroups through the Girvan - Newman algorithm (Girvan and Newman 2002). We then check for boundary spanning behaviours among groups considering the between centrality $(B C)$ of nodes, which measures the extent to which a vertex 
lies on paths between other vertices. Nodes with high betweeness centrality can be considered as "bridges" connecting subgroups (Jaja et al. 2016). They are thus in the position for initiating or supporting collaboration, as they can coordinate the activities of subgroups towards a common goal (Bodin and Crona 2009). Beyond betweeness centrality, we also compute nodes' degree centrality (DC) to assess the influence of single actors in the network and thus spot possible enablers for change. Finally, network centralization (NC) provides a sense of how much influence is concentrated or spread across the network. It is based on calculating the variability in centralities among the network members (Wasserman and Faust 1994).

\subsection{ASSESSING COMMUNITY ARTICULATION AND INSTITUTIONAL ACCESS}

The analysis on community bonding (community articulation) and linking (institutional access) ties was based on data on social capital we collected through face-to-face structured interviews ( $\mathrm{n}=90$ ) in the communities of Cor. Andrés Sánchez Magallanes, Ejido Alacran and Colonia Agraria Las Flores in Cardenas (March 2015). We focused on Cardenas as the biggest municipality, in terms of population, of the C-P-M lagoon system (INEGI 2015). Sampled communities were chosen for their proximity to the coast, patterns of socio-economic vulnerability, and exposure to climatic and anthropic pressures. Demographic representativeness was considered, although giving priority to communities relying on productive activities potentially impacted by changes in water quality and soil fertility (i.e. fisheries, livestock and agriculture).

We analysed answers to following questions as measures of social network support (Scrivens and Smith 2013): 1) "In case of economic problems, who do you ask for help?"; 2) "In case of economic problems, who would you help?" Responses included: i) family; ii) friends; iii) members of the Cooperatives/Unions; iv) other people; v) nobody. We also analysed answers on trust in neighbours ("How much do you trust neighbours?") to get a sense of community cohesiveness. For linking ties, we focused on the question "How much do you trust: i) Political Parties; ii) Unions; iii) Cooperatives; iv) Governments; v) the Church". On the basis of the preliminary results on trust, follow up interviews were carried out with community members in the context of a second workshop with local stakeholders in June 2015 (Giannini et al. 2017).

\section{RESULTS}

\subsection{INSTITUTIONAL ARTICULATION}

Figure 2 provides a first overview of the links among organizations that work or have an interest in CCA/DRR activities in Tabasco. Colours are used to represent either their main scope of activity (economic, environmental, social, planning, civil protection, academic) or the particular nature of 
the actor. Indeed, actors such as the municipality and communities of Cárdenas are somehow "hybrid", as they could both be deliverers or recipients of adaptation actions depending on the governance setting (top- down or co-management). Undirected lines of different width represent links among actors, so to express increasing strengths in the relationship (information exchange; coordination; collaboration). Finally, the dimension of nodes indicates the different values of degree centrality scored by each actor.

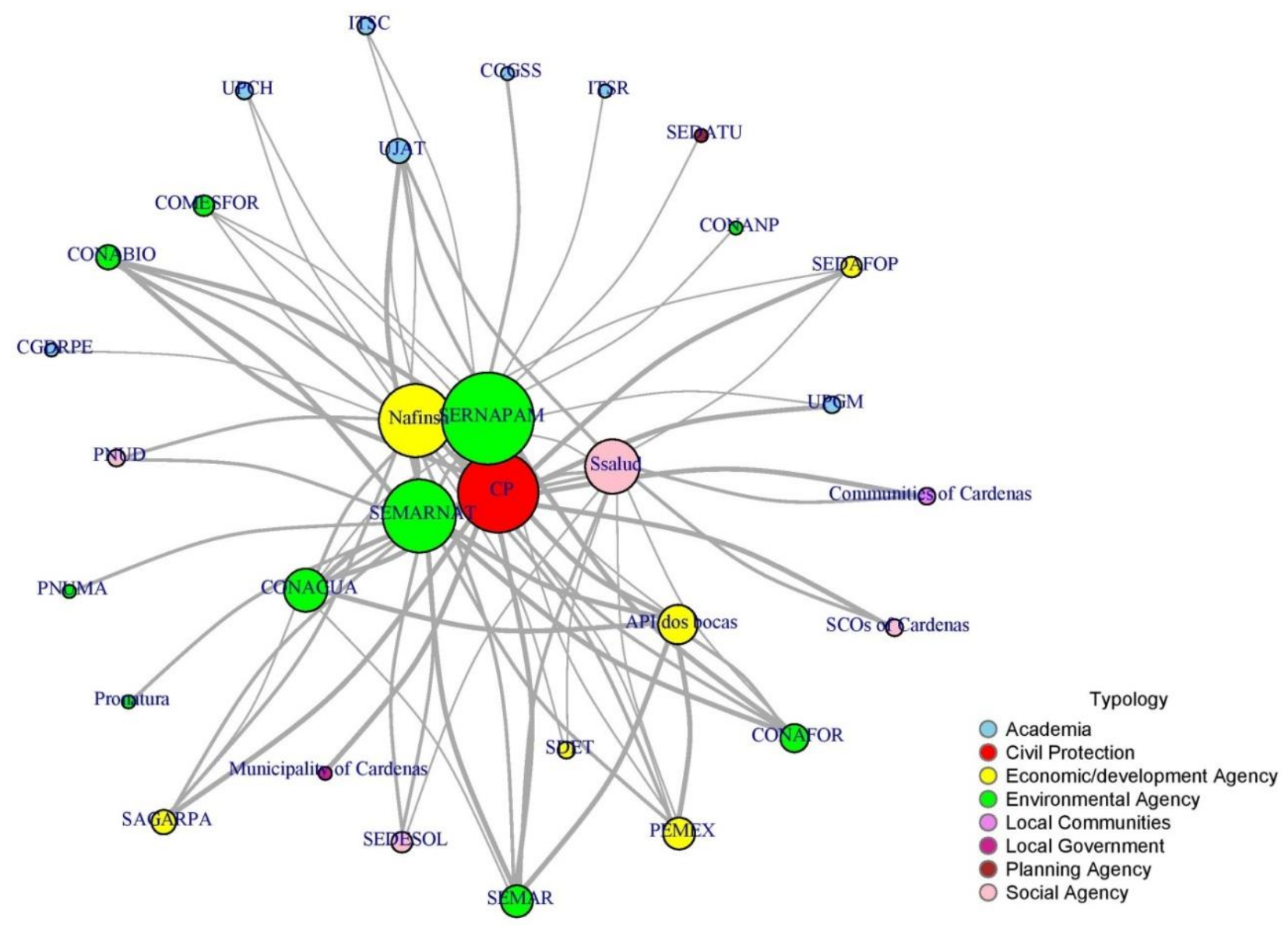

Figure 2: Network of organizations working or interested in DRR/CCA in Tabasco

SERNAPAM shows the highest degree centrality, followed by $\mathrm{CP}$, Nafinsa, and SEMARNAT (see also Table 2 in Annex 1). The influential role of SERNAPAM is not surprising as the Agency is explicitly mandated by the Environmental Protection Law of the state of Tabasco (TABASCO 2013) of planning and implementation functions in the field of environmental protection, including climate change adaptation. At a higher administrative level, this is also the case for SEMARNAT, i.e. the Ministry of Environment, and the $\mathrm{CP}$, in terms of disaster response. The centrality of Nafinsa is to be read through different lenses, as the Agency is in charge of disbursing the funds by the Federal Government and International Organizations (WB, FMI, IDB) to different projects, including adaptation. The concentration of influence in this small number of actors is also indicated by the high centralization score of the network $(\mathrm{NC}=0,57)$ 
In Figure 3, the clustering algorithm is applied to detect the existence of subgroups. Interestingly, a quite compartmentalised network structure is revealed and three subgroups become evident (red, yellow, and green areas). The biggest one (red) tends to group Agencies with an environmental mandate and pertaining to the Federal level (SEMARNAT, CONAGUA, SEMAR, CONABIO, CONAFOR). The group is quite tightly linked and mostly connected by collaboration-type ties. Moreover, these institutions have fewer boundary spanning ties (in red) which makes the group relatively closed. SERNAPAM acts as a bridge between the red and the yellow clusters, as also shown by its degree of betweeness centrality (Table 2). The yellow subgroup is characterised by a core-periphery structure, where academic entities -the most represented actors in the subgroup are individually linked to SERNAPAM. This hints to the capacity of SERNAPAM to engage in knowledge and information exchange with local Universities, but also the lack of interchange among the latter. Finally, the third cluster groups the communities and SCOs of Cardenas and State entities devoted to local development around the Secretary of Health (SSalud) of Tabasco.

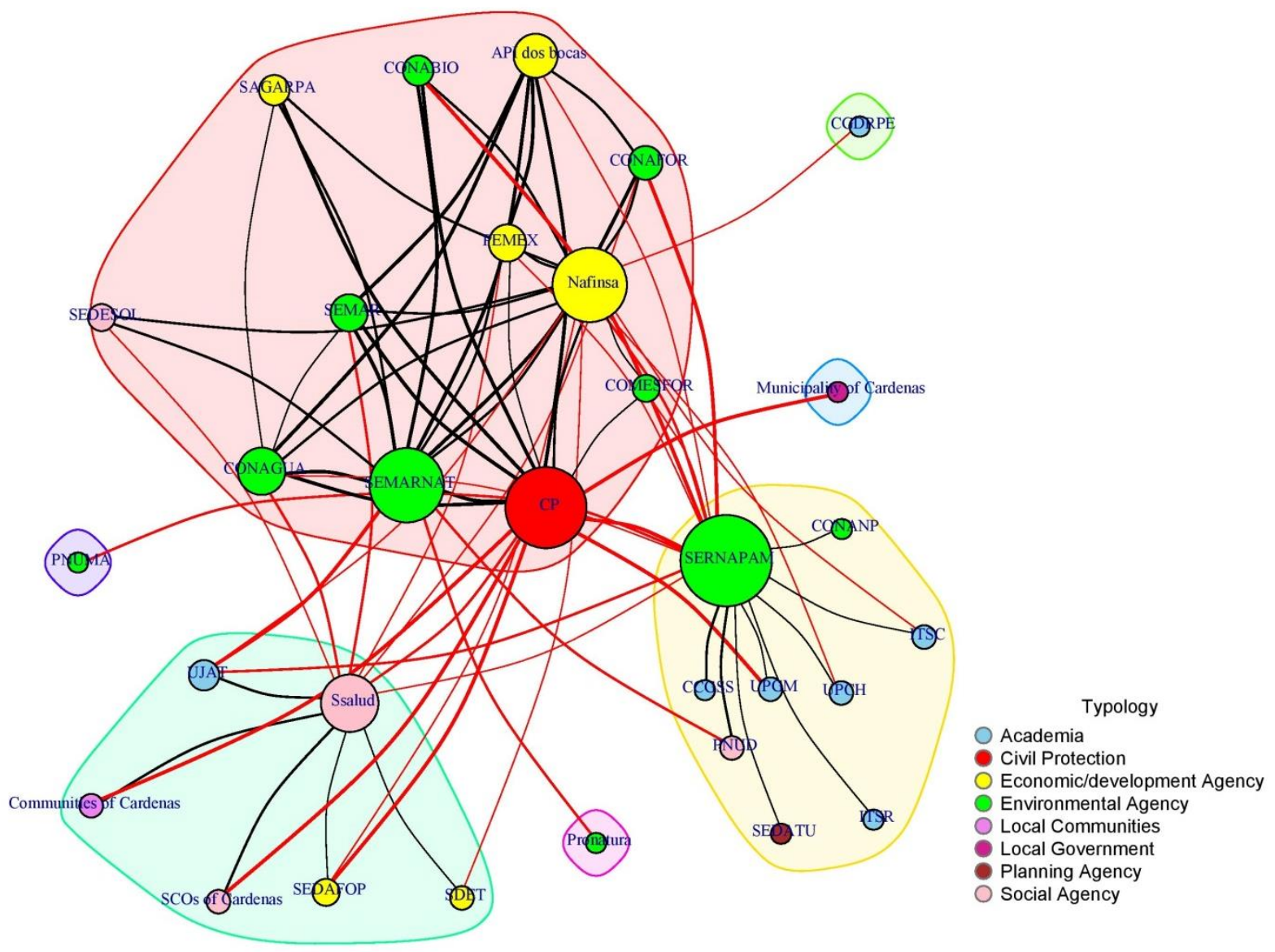

Figure 3: Fragmentation of the DRR/CCA network in subgroups

A number of considerations can be made by looking at both the network structure and associated statistics. To start with, the clusters tend to group homogeneous actors in terms of mandate: federal agencies operating on environmental issues in the red one; local Universities providing technical knowledge to a local environmental entity (SERNAPAM) in the yellow; and organisations dealing 
with socio-economic issues with local communities in the green one. The existence of these subgroups points to the existence of diverse and complementary knowledge that can be usefully employed for the resolution of the problem at hand (here DRR/CCA). Yet, their relative contribution is unbalanced as DRR/CCA issues seems to be predominantly dealt with from an environmental perspective, i.e. trough collaboration among environmental entities (as for the red cluster) and resorting to the knowledge provided by local technical University (such as UPGM, ITSR, ITSC).

In order to enhance resilience, different dimensions of vulnerability - social, economic, cultural and institutional- need to be addressed on top of physical and environmental ones (Birkmann et al. 2013, Schneiderbauer et al. 2017). Socio-economic considerations are of particular relevance in the C-P-M site, where poverty, marginalisation and the low human development of communities are among the main drivers behind the overexploitation of local ecosystems. Attention to socio-economic aspects in the governance system could be increased by exploiting the bridging role of SSalud (BC= $0,26)$, which is in charge of public health responses when a disaster strikes. Together with $C P$, SSalud is indeed the only entity to have ties with local communities and that could therefore act as a mediator between them and federal agencies such as CONAGUA, CONAFOR, and SEMAR. The same role could be envisaged for enhancing inter-sectoral cooperation across levels of governments and connect federal environmental entities with state organization having economic priorities like SEDAFOP and SDET.

Figure 3 also shows that efforts should be directed in increasing horizontal cooperation, i.e. among actors at the same level of government. While degree centrality makes SERNAPAM the most influential actor in the network, a closer look reveals that its connections with other specialised state agencies are at best scant. The only tie reported is that with COMESFOR, i.e. the State forestry agency. This casts doubts on the effectiveness of the Inter-Secretarial Commission on Climate Change of the state of Tabasco, mandated by the Environmental Protection Law (TABASCO 2013). Chaired by SERNAPAM, the Commission has met episodically and has taken no substantive actions so far (Carlon 2016). The fact importantly highlights that, when underlining social networks are missing, formal laws or regulations mandating cooperation are no guarantee that it will actually take place.

Finally, the centrality of actors like SSalud and CP tells something about the type of collective action currently taking place in Tabasco with respect to DRR/CCA. As both the organizations largely rely on a reactive approach, actions seem to be oriented towards emergency response instead of prevention.

\subsection{COMMUNITY ARTICULATION}

Results on community articulation show the existence of strong bonding ties at the family level. When answering questions about providing/asking for help in case of economic problems, respondents largely indicated their family as the actor they would support or be supported by (75\% and $85,9 \%$ ). Interestingly, $7 \%$ of them would prefer not to ask for anybody's help rather than 
referring to the listed entities (Figure 4). When asked about the degree of trust they had in neighbours, $24.4 \%$ respondents said they had none and $40 \%$ little.

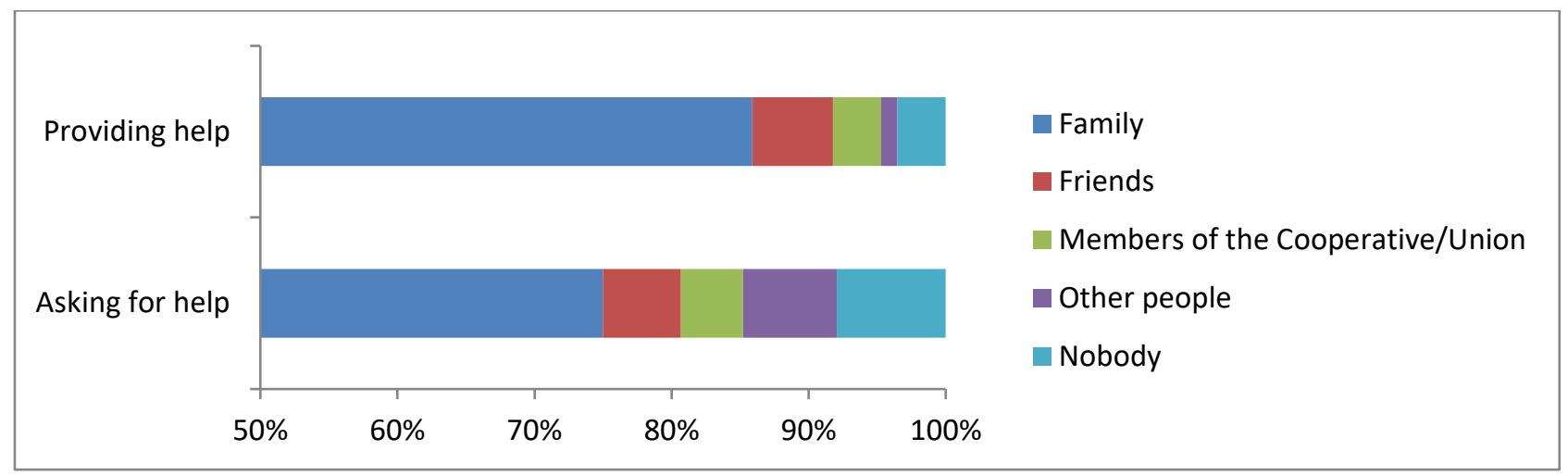

Figure 4: Social networks in case of economic problems

Taken together, these results depict an atomised society. Interviews with local experts attributed the disruption of social fabric to the rapid changes in environmental conditions brought about by the salinization of the lagoon system due to the artificial widening of the Panteón harbour mouth (see Figure 1). According to experts, salinization would have led to the loss of traditional livelihoods, based in particular on ranching and coconut farming, and to a severe worsening of living conditions that eventually undermined solidarity at the community level.

While bonding ties can be useful for survival or recovery from natural disasters (Pelling 2003), densely nucleated networks have also proved to be unable to deal with vast changes (Newman \& Dale, 2005). They have the effect of closing up society in small units and make interactions and flows of information difficult (Pelling and High 2005). They can also inhibit innovation (Dowd et al. 2014): for instance, women involved in a community-based adaptation project in Cardenas reported they were regarded with suspicion by other community members and had an hard time in convincing them to join ${ }^{4}$. Bridging ties are therefore needed to mobilise the community towards forwardlooking adaptation objectives and to foster proactive behaviours. There is no one-fits-all solution for restoring or recreating them as interventions necessarily need to build upon the consideration of very specific communities' internal dynamics (Krishna and Shrader 2000). However, research has shown that local level organizations -as operating strictly within a community - can play an important role in that and so can carefully designed outside intervention (Grootaert and Van Bastelaer 2002).

\footnotetext{
${ }^{4}$ Personal communication with the authors during the workshop with community members in June 2015.
} 


\subsection{INSTITUTIONAL ACCESS}

Local communities express particularly high level of distrust in governmental authorities and in intermediate governance levels like labour unions, political parties and cooperatives (Figure 5). The only notable exception is represented by the Churches and other religious institutions, gaining the trust of $95.65 \%$ of the people interviewed.

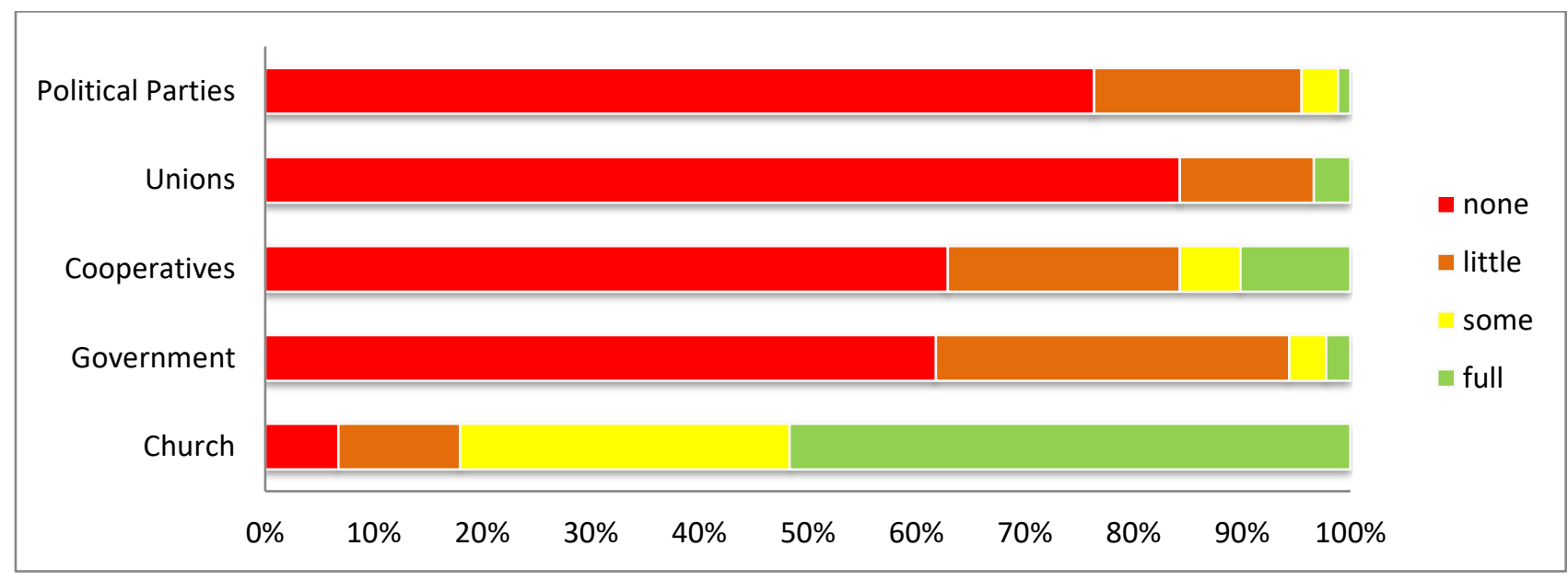

Figure 5 : Trust of the communities of Cardenas in formal institutions

These results are very important in highlighting the lack of legitimacy any intervention by public authorities needs to cope with in the study area. With a specific focus on DRR/CCA, responses gained through follow-up interviews spotted top three institutions attracting distrust and including the municipality of Cardenas, PEMEX and COMESFOR. In the case of COMESFOR, this was justified by the "lack of participation in the social sector" as put by one of the interviewed (Respondents n. 16). On the contrary, institutions communities trust the most are SEDESOL, SEMARNAT and SAGARPA, which deal with social development, environmental issues and rural development respectively.

These results suggest important entry points for intervention. Firstly, they call for a greater engagement of organisations with social and economic mandates as they seem to have the legitimacy needed in dealing with and mobilising communities. The relevance of socio-economic issues for community members also suggests an enhanced integration of these concerns in climate adaptation interventions as a way to possibly enhance their effectiveness. Secondly, the high trust communities have in religious entities could be exploited as a catalyst for behavioural change and mobilisation at the community level. For instance, Churches proved to be successful in conveying information and virtuous behaviours related to DRR/CCA in Guatemala and other Central American countries (Alianza ACT 2011). 


\section{DISCUSSION}

Collaboration barriers have been reported among the most frequent constraints to adaptation. However, the growing literature on the topic has largely been descriptive and limited attention has been placed on how to transform barriers into enablers for action. While barriers may arise in all phases of the adaptation process (Moser and Ekstrom 2010), our work considered those implied in moving from the planning to the implementation phase. These barriers may arise from the same way adaptation plans have been designed. An evaluation of first generation adaptation plans in developed nations showed how only a small minority of them had designed clear implementation pathways (Preston et al. 2010). More recently, Woodruff and Stults (2016) found that local adaptation plans in the United States (US) lacked clear mechanisms and prioritization for translating objectives into on-the-ground projects. However, formal public institutions, like procedures, plans, laws and regulations, are only part of the story. No matter how carefully the latter are designed, final adaptation outcomes will eventually be shaped by tacit informal norms, codes and conducts.

Indeed, malcoordination across different level of governments and stakeholders, weakor nonexistent ties across organizations and conflicting interests and objectives can significantly inhibit adaptation outcomes. Actors might engage in a network only to advance their own interests (Bodin 2017) and eventually undermine the definition of a joint solution for the common problem at hand. Aligning individual interests with collective ones requires trust and transparency, and the creation, maintenance and functioning of common rules though the network (McAllister et al. 2017). The lack of shared norms is evident, for instance, in the case of the Inter-Secretarial Commission on Climate Change of the state of Tabasco: although mandated by the law, the model of collaboration it embeds is not borne out on the ground, probably because of a lack of ownership or interest of local actors in this institution. While a quantitative SNA alone might be limited in investigating these fundamental aspects, the mixed-methods approach presented in this paper still allows for gaining first interesting insights on the way a mismatch between formal and informal institutions might drive socioecological systems towards inadequate adaptation outcomes. The use of complementary methods like ethnography would be beneficial in this attempt.

The application presented in the paper importantly highlights some aspects worth considering when applying SNA on the ground. A first one, in fact common to almost all applications of SNA, relates to the possibility of missing some important actors of the network (Bharwani et al. 2013). This can be due to limitations of the preparatory institutional mapping or to the unavailability of specific institutions to be surveyed. To circumvent this issue, a specific data collection activity was designed in our case study as part of a wider workshop discussing adaptation options in the area of interest. Although this cannot assure that the whole network will be captured, it ensures that a sample of representative actors is surveyed as their participation to the workshop signals involvement or at least interest in adaptation activities in the case study area. It should also be noted that the workshop per se can be seen as a mean for building or strengthening the governance network, as participants have the opportunity to get to know each other's work better and to create personal links if 
participatory activities are designed. Another common limitation of quantitative SNA is its tendency to focus on methodological and technical issues which, coupled with weaknesses in the sampling process, can lead to an over-interpretation of findings (Bharwani et al. 2013). As a way to address this aspect, we complemented the analysis with face-to-face interviews with local experts, so that results could be better contextualised.

An additional consideration can be made with respect to the way local communities are integrated in the analysis. In our case study, it was possible to carry out a quantitative SNA among formal organizations only. In principle, community leaders can also be involved in the exercise, yet we had to face two main issues: i) the low literacy rate of coastal communities that made it hard to engage them in intensive data collection processes and; 2) the paucity of adaptation interventions in the case study area, hampering the possibility to detect actual connections in the DRR/CCA context. The concept of trust proved to be particularly useful to overcome these limitations and to capture the potential for collaboration. While reflecting the predisposition to engage in more tight relationships, the concept of trust also allowed for identifying entry points for intervention. As an example, the legitimation certain organizations have in the eyes of local communities can be exploited to mobilise the latter towards DRR/CCA objectives.

\section{CONCLUSIONS}

The paper applied social network analysis to reveal the actual web of connections tying stakeholders, identify shortcomings in the structure, and propose ways to tackle them so that the full potential of adaptation can be exploited. Following recent research on collaborative environmental governance (Bodin 2017), concurrent consideration was given to: $i)$ who the actors working or interested in DRR/CCA are; ii) what are the networks through which they collaborate; and iii) how the structure of the "collaborative network" relates to their abilities to address the problems.

A mixed-method approach, combining both a quantitative and a qualitative SNA was employed to assess the strength and nature of links among i) formal organizations engaged in DRR/CCA in the site; ii) community members; and iii) formal organization and community members. It was designed to account for the high illiteracy rates characterising the case study area and which would have made it difficult to fully engage local communities in the intensive data collection process required for a sole quantitative SNA.

The approach proved to be fruitful for the identification of implementation constraints and the elaboration of strategies to overcome them, and yields potential for replication. In particular, the application of the quantitative SNA to the case study showed how solutions can be elaborated based on its descriptive and diagnostic potential. As a descriptive tool, SNA maps the relational architecture of the system of interest. It makes it possible to reveal network characteristics that are important for collective action including: network fragmentation in subgroups; density of relations; centralization 
around a few actors. In the case study, the distinction among i) information exchange; ii) coordination; iii) and collaboration ties, also allowed for appreciating the different nature and strength of relations. In terms of actors, SNA spots those that are isolated and those that are well connected and thus more influential in the network. As a diagnostic tool, the actual topology of the network can be compared with what is required for achieving desired adaptation outcomes. It thus allows for answering important questions including: Is multi-level integration achieved? What is the extent of collaboration among different types of actors? Are relevant actors or connections missing? Vertical (linking ties) and horizontal (bonding ties) connection among actors can thus be explored both visually and algorithmically. Should integration be limited, measures like betweeness centrality can identify boundary-spanning actors to be used for enhancing network cohesion. In case of missing actors or links, ad-hoc strategies for building inter-institutional relations can also be designed. Yet, the paper also showed how a quantitative SNA might not be applicable to all contexts and how complementary methods might be needed. The concept of trust was employed here to capture the potential for collaboration and assess community bonding and linking ties. By focusing this concept, it was equally possible to identify entry points for intervention by spotting organizations that can mobilise communities towards DRR/CCA objectives

The mixed-method approach presented in the paper -combining a quantitative and qualitative SNA - can thus be useful for better accounting for the complexity of local situations and of the specific socio-institutional interplays which drive local adaptation outcomes. The paper thus demonstrates the applicability of a social network analytical approach to a variety of contexts with the aim of supporting effective collaborative arrangements in adaptation governance.

\section{ACKNOWLEDGEMENTS}

This work was supported by the European Commission's Horizon 2020 research \& innovation programme under the Placard (PLAtform for Climate Adaptation and Risk reDuction) [Grant agreement No. 653255] and the CCLAD (The Politics of Climate Change Loss and Damage) project [Grant agreement No. 755753 - CCLAD - ERC-2017-STG] projects. 
AnNex 1

Table 2: Normalised values of degree and betweeness centrality for organisations in the DRR/CCA network

\begin{tabular}{|c|c|c|c|}
\hline Names & $\begin{array}{l}\text { Degree } \\
\text { (Norm.) }\end{array}$ & Names & Betweeness (Norm.) \\
\hline SERNAPAM & 0,733 & SERNAPAM & 0,541 \\
\hline CP & 0,633 & Ssalud & 0,259 \\
\hline Nafinsa & 0,567 & Nafinsa & 0,178 \\
\hline SEMARNAT & 0,567 & SEMARNAT & 0,137 \\
\hline Ssalud & 0,400 & $\mathrm{CP}$ & 0,082 \\
\hline CONAGUA & 0,300 & CONAGUA & 0,081 \\
\hline API dos bocas & 0,267 & COMESFOR & 0,030 \\
\hline PEMEX & 0,200 & PEMEX & 0,019 \\
\hline SEMAR & 0,200 & ITSC & 0,009 \\
\hline CONAFOR & 0,167 & UPCH & 0,009 \\
\hline CONABIO & 0,133 & SDET & 0,009 \\
\hline SAGARPA & 0,133 & SEDAFOP & 0,009 \\
\hline UJAT & 0,133 & API dos bocas & 0,000 \\
\hline COMESFOR & 0,100 & CCGSS & 0,000 \\
\hline SEDAFOP & 0,100 & CGDRPE & 0,000 \\
\hline SEDESOL & 0,100 & Communities of Cardenas & 0,000 \\
\hline Communities of Cardenas & 0,067 & CONABIO & 0,000 \\
\hline ITSC & 0,067 & CONAFOR & 0,000 \\
\hline PNUD & 0,067 & CONANP & 0,000 \\
\hline SCOs of Cardenas & 0,067 & ITSR & 0,000 \\
\hline SDET & 0,067 & Municipality of Cardenas & 0,000 \\
\hline UPCH & 0,067 & PNUD & 0,000 \\
\hline UPGM & 0,067 & PNUMA & 0,000 \\
\hline CCGSS & 0,033 & Pronatura & 0,000 \\
\hline CGDRPE & 0,033 & SAGARPA & 0,000 \\
\hline CONANP & 0,033 & SCOs of Cardenas & 0,000 \\
\hline ITSR & 0,033 & SEDATU & 0,000 \\
\hline Municipality of Cardenas & 0,033 & SEDESOL & 0,000 \\
\hline PNUMA & 0,033 & SEMAR & 0,000 \\
\hline Pronatura & 0,033 & UJAT & 0,000 \\
\hline SEDATU & 0,033 & UPGM & 0,000 \\
\hline
\end{tabular}




\section{REFERENCES}

Adger, N., 2003. Social Capital, Collective Action, and Adaptation to Climate Change. Economic Geography, 79 (4), 387-404.

Adger, W.N., Agrawala, S., Mirza, M.M.Q., Conde, C., O’Brien, K., Pulhin, J., Pulwarty, R., Smit, B., and Takahashi, K., 2007. Assessment of adaptation practices, options, constraints and capacity Coordinating Lead Authors: Lead Authors. In: M.L. Parry, O.F. Canziani, J.P. Palutikof, and C.E. van der Linden, P.J. Hanson, eds. Climate Change 2007: Impacts, Adaptation and Vulnerability. Contribution of Working Group II to the Fourth Assessment Report of the Intergovernmental Panel on Climate Change. Cambridge, UK: Cambridge University Press, 717-743.

Agrawal, A., 2010. The Role of Local Institutions in Adaptation to climate change. In: R. Mearns and A. Norton, eds. Social dimensions of climate change: Equity and vulnerability in a warming world. Washington: The World Bank.

Alianza ACT, 2011. Sistematización de Iniciativas de Gestión de Riesgos en Centroamérica Concertación Regional para la Gestión de Riesgos en Centroamérica.

Azhoni, A., Holman, I., and Jude, S., 2017. Adapting water management to climate change: Institutional involvement, inter-institutional networks and barriers in India. Global Environmental Change, 44, 144157.

Barnett, J., Evans, L.S., Gross, C., Kiem, A.S., Kingsford, R.T., Palutikof, J.P., Pickering, C.M., and Smithers, S.G., 2015. From barriers to limits to climate change adaptation: Path dependency and the speed of change. Ecology and Society, 20 (3).

Beltrán, J.E., 1988. Petróleo y desarrollo : la política petrolera en Tabasco. 2nd editio. Villahermosa, Tabasco: Gobierno del Estado de Tabasco.

Berkhout, F., 2012. Adaptation to climate change by organizations. Wiley Interdisciplinary Reviews: Climate Change, 3 (1), 91-106.

Bhagavan, M.R. and Virgin, I., 2004. Generic Aspects of Institutional Capacity Development in Developing Countries. Stockholm.

Bharwani, S., Downing, T.E., Varela-Ortega, C., Blanco, I., Esteve, P., Carmona, G., Taylor, R., Devisscher, T., Coll Besa, M., Tainio, A., Ballard, D., and Watkiss, P., 2013. Social Network Analysis: Decision Support Methods for Adaptation, MEDIATION Project, Briefing Note 8.

Biesbroek, G.R., Klostermann, J.E.M., Termeer, C.J.A.M., and Kabat, P., 2013. On the nature of barriers to climate change adaptation. Regional Environmental Change, 13 (5), 1119-1129.

Birkmann, J., Cardona, O.D., Carreno, M.L., Barbat, A.H., Pelling, M., Schneiderbauer, S., Kienberger, S., M.Keiler, Alexander, D., Zeil, P., and T., W., 2013. Framing vulnerability, risk and societal responses : the MOVE framework. Nat Hazards, 67, 193-211.

Bodin, Ö., 2017. Collaborative environmental governance: Achieving collective action in social-ecological systems. Science, 357 (6352), eaan1114. 
Bodin, Ö. and Crona, B., 2009. The role of social networks in natural resource governance: What relational patterns make a difference? Global Environmental Change, 19 (3), 366-374.

Bodin, Ö. and Norberg, J., 2005. Information network topologies for enhanced local adaptive management. Environmental Management, 35 (2), 175-193.

Bodin, Ö., Robins, G., McAllister, R.R.J., Guerrero, A.M., Crona, B., Tengö, M., and Lubell, M., 2016. Theorizing benefits and constraints in collaborative environmental governance: A transdisciplinary social-ecological network approach for empirical investigations. Ecology and Society, 21 (1).

Borgatti, S.P., Mehra, A., Brass, D.J., and Labianca, G., 2009. Network Analysis in the Social Sciences. Science, 323 (5916).

Bowen, K.J., Alexander, D., Miller, F., and Dany, V., 2014. Using social network analysis to evaluate healthrelated adaptation decision-making in Cambodia. International journal of environmental research and public health, 11 (2), 1605-25.

Buenfil Friedman, J., 2009. Adaptacion a los impactos del cambio climático en los humedales costeros del Golfo de México (Vol. 2). Mexico, D.F.: Secretaría de Medio Ambiente y Recursos Naturales.

Carlon, O., 2016. The Role of Institutions in the Adaptation Discourse: Results from Social Network Analysis in Tabasco, Mexico . Ca Foscari university of Venice.

Chambwera, M., Heal, G., Dubeux, C., Hallegatte, S., Leclerc, L., Markandya, A., McCarl, B.A., Mechler, R., and Neumann, J.E., 2014. Economics of adaptation. In: C.B. Field, V.R. Barros, D.J. Dokken, K.J. Mach, M.D. Mastrandrea, T.E. Bilir, M. Chatterjee, K.L. Ebi, Y.O. Estrada, R.C. Genova, B. Girma, E.S. Kissel, A.N. Levy, S. MacCracken, P.R. Mastrandrea, and L.L. White, eds. Climate Change 2014: Impacts, Adaptation, and Vulnerability. Part A: Global and Sectoral Aspects. Contribution of Working Group II to the Fifth Assessment Report of the Intergovernmental Panel of Climate Change. Cambridge, United Kingdom and New York, NY, USA: Cambridge University Press, 945-977.

CONEVAL, 2010. Medición de la pobreza en México 2010, a escala municipal.

Corfee-Morlot, J., Kamal-Chaoui, L., Donovan, M.G., Cochran, I., Robert, A., Teasdale, P.J., Corfee-Morlot, J., Kamal-Chaoui, L., Donovan, M.G., Cochran, I., Robert, A., and Teasdale, P.-J., 2009. Cities, Climate Change and Multilevel Governance. Paris, No. 14.

Csardi, G. and Nepusz, T., 2006. The igraph software package for complex network research. InterJournal, Complex Sy.

Cunningham, R., Cvitanovic, C., Measham, T., Jacobs, B., Dowd, A.-M., and Harman, B., 2016. Engaging communities in climate adaptation: the potential of social networks. Climate Policy, 16 (7), 894-908.

Dixit, A., Mcgray, H., Gonzales, J., and Desmond, M., 2012. Ready or Not : Assessing National Institutional Capacity for Climate Change Adaptation. $n$. Lessons for Planners from the Pilot Applications of the National Adaptive Capacity Framework. Washington DC.

Dow, K., Berkhout, F., Preston, B.L., Klein, R.J.T., Midgley, G., and Shaw, M.R., 2013. Limits to adaptation. Nature Climate Change, 3 (4), 305-307. 
Dowd, A.-M., Marshall, N., Fleming, A., Jakku, E., Gaillard, E., and Howden, M., 2014. The role of networks in transforming Australian agriculture. Nature Climate Change, 4 (7), 558-563.

Eisenack, K., Moser, S.C., Hoffmann, E., Klein, R.J.T., Oberlack, C., Pechan, A., Rotter, M., and Termeer, C.J. a. M., 2014. Explaining and overcoming barriers to climate change adaptation. Nature Climate Change, 4 (10), 867-872.

Engle, N.L., 2011. Adaptive capacity and its assessment. Global Environmental Change, 21 (2), 647-656.

Eriksen, S. and Lind, J., 2009. Adaptation as a Political Process: Adjusting to Drought and Conflict in Kenya's Drylands. Environmental Management, 43 (5), 817-835.

Folke, C., Hahn, T., Olsson, P., and Norberg, J., 2005. Adaptive Governance of Social-Ecological Systems. Annual Review of Environment and Resources, 30 (1), 441-473.

Giannini, V., Ramieri, E., Caso Chávez, M., Santos del Prado Gasca, K., and Priego Martínez, K., 2017. A participatory process to design climate change adaptation measures for the Carmen-Pajonal-Machona lagoon system in Mexico. In: W. Leal Filho and J. Keenan, eds. Climate change adaptation in North America. Fostering resilience and the regional capacity to adapt. Springer, 27-49.

Girvan, M. and Newman, M.E.J., 2002. Community structure in social and biological networks. Proceedings of the National Academy of Sciences, 99 (12), 7821-7826.

Gliessman, S.R., 2014. Agroecology: the ecology of sustainable food systems. 3rd editio. New York, USA: CRC Press.

Grootaert, C. and Van Bastelaer, T., 2002. The role of social capital in development : an empirical assessment. Cambridge, UK: Cambridge University Press.

Grothmann, T., Grecksch, K., Winges, M., and Siebenhüner, B., 2013. Assessing institutional capacities to adapt to climate change: integrating psychological dimensions in the Adaptive Capacity Wheel. Natural Hazards and Earth System Science, 13 (12), 3369-3384.

Gupta, J., Termeer, C., Klostermann, J., Meijerink, S., van den Brink, M., Jong, P., Nooteboom, S., and Bergsma, E., 2010. The Adaptive Capacity Wheel: a method to assess the inherent characteristics of institutions to enable the adaptive capacity of society. Environmental Science \& Policy, 13 (6), 459471.

Hawkins, R.L. and Maurer, K., 2010. Bonding, bridging and linking: How social capital operated in New Orleans following Hurricane Katrina. British Journal of Social Work, 40 (6), 1777-1793.

Hodgson, G.M., 2006. What Are Institutions? JOURNAL OF ECONOMIC ISSUES, XL (1), 1-25.

Holland, J., 2007. Tools for Institutional, Political, and Social Analysis of Policy Reform A Sourcebook for Development Practitioners. Washington: The International Bank for Reconstruction and Development / The World Bank.

INEGI, 2015. Encuesta Intercensal 2015 [online]. Available from: http://www.beta.inegi.org.mx/proyectos/enchogares/especiales/intercensal/ [Accessed 19 Sep 2017]. 
Ingold, K., Balsiger, J., and Hirschi, C., 2010. Climate change in mountain regions: how local communities adapt to extreme events. Local Environment, 15 (7), 651-661.

Jaja, J., Dawson, J., and Gaudet, J., 2016. Using Social Network Analysis to examine the role that institutional integration plays in community-based adaptive capacity to climate change in Caribbean small island communities. Local Environment, 9839 (August), 1-19.

Jones, E.C. and Faas, A.J., 2017. Social network analysis of disaster response, recovery, and adaptation. Oxford (UK) and Cambridge (USA): Butterworth-Heinemann.

Klein, R.J.T., Midgley, G.F., Preston, B.L., Alam, M., Berkhout, F.G.H., Dow, K., and Shaw, M.R., 2014. Adaptation opportunities, constraints, and limits. In: C.B. Field, V.R. Barros, D.J. Dokken, K.J. Mach, M.D. Mastrandrea, T.E. Bilir, M. Chatterjee, K.L. Ebi, Y.O. Estrada, R.C. Genova, B. Girma, E.S. Kissel, A.N. Levy, S. MacCracken, P.R. Mastrandrea, and L.L. White, eds. Climate Change 2014: Impacts, Adaptation, and Vulnerability. Part A: Global and Sectoral Aspects. Contribution of Working Group II to the Fifth Assessment Report of the Intergovernmental Panel of Climate Change. Cambridge, United Kingdom and New York, NY, USA: Cambridge University Press, 899-943.

Koontz, T.M., Gupta, D., Mudliar, P., and Ranjan, P., 2015. Adaptive institutions in social-ecological systems governance: A synthesis framework. Environmental Science \& Policy, 53, 139-151.

Krishna, A. and Shrader, E., 2000. CROSS-CULTURAL MEASURES OF SOCIAL CAPITAL: A TOOL AND RESULTS FROM INDIA AND PANAMA. Washington, DC, No. 21.

Luthe, T., Wyss, R., and Schuckert, M., 2012. Network governance and regional resilience to climate change: Empirical evidence from mountain tourism communities in the Swiss Gotthard region. Regional Environmental Change, 12 (4), 839-854.

Marsden, P., 1990. Network Data and Measurement. Annual Review of Sociology, 16 (1990), 435-463.

Marwell, G., Oliver, P.E., and Prahl, R., 1988. Social Networks and Collective Action: A Theory of the Critical Mass. III. American Journal of Sociology, 94 (3), 502-534.

McAllister, R.R.J., Robinson, C.J., Brown, A., Maclean, K., Perry, S., and Liu, S., 2017. Balancing collaboration with coordination: Contesting eradication in the Australian plant pest and disease biosecurity system. International Journal of the Commons, 11 (1), 330-354.

Mimura, N., Pulwarty, R.S., Duc, D.M., Elshinnawy, I., Redsteer, M.H., Huang, H.Q., Nkem, J.N., and Sanchez Rodriguez, R.A., 2014. Adaptation planning and implementation. In: K.J.M. Field, C.B., V.R. Barros, D.J. Dokken and and L.L.W. M.D. Mastrandrea, T.E. Bilir, M. Chatterjee, K.L. Ebi, Y.O. Estrada, R.C. Genova, B. Girma, E.S. Kissel, A.N. Levy, S. MacCracken, P.R. Mastrandrea, eds. Climate Change 2014: Impacts, Adaptation, and Vulnerability. Part A: Global and Sectoral Aspects. Contribution of Working Group II to the Fifth Assessment Report of the Intergovernmental Panel on Climate Change. Cambridge: Cambridge University Press, 869-898.

Moser, S.C. and Ekstrom, J.A., 2010. A framework to diagnose barriers to climate change adaptation. Proceedings of the National Academy of Sciences of the United States of America, 107 (51), 22026-31. 
Negrete Salas, M.E., 1984. Petróleo Y Desarrollo Regional: El Caso De Tabasco. Demografía y economía, 18 (1), 86-109.

Newman, L. and Dale, A., 2005. Network Structure, Diversity, and Proactive Resilience Building: a Response to Tompkins and Adger. Ecology and Society, 10 (1), [online].

Nightingale, A.J., 2017. Power and politics in climate change adaptation efforts: Struggles over authority and recognition in the context of political instability. Geoforum, 84, 11-20.

North, D.C., 1990. Institutions, Institutional Change and Economic Performance. Political Economy of Institutions and Decisions. Cambridge: Cambridge University Press.

Oberlack, C., 2017. Diagnosing institutional barriers and opportunities for adaptation to climate change. Mitigation and Adaptation Strategies for Global Change, 22 (5), 805-838.

Ostrom, E., 1990. Governing the Commons: The Evolution of Institutions for Collective Action. The Political Economy of Institutions and Decisions. Cambridge: Cambridge University Press.

Ostrom, E., 2010. Polycentric systems for coping with collective action and global environmental change. Global Environmental Change, 20 (4), 550-557.

Pelling, M., 1998. Participation, social capital and vulnerability to urban flooding in Guyana. Journal of International Development, 10 (4), 469-486.

Pelling, M., 2003. The vulnerability of cities : natural disasters and social resilience. Earthscan Publications.

Pelling, M. and High, C., 2005. Understanding adaptation: What can social capital offer assessments of adaptive capacity? Global Environmental Change, 15, 308-319.

Pinkus Rendón, M.J. and Contreras-Sánchez, A., 2013. Impacto socioambiental de la industria petrolera en Tabasco: el caso de la Chontalpa. LiminaR. Estudios Sociales y Humanísticos, 10 (2), 122.

Prell, C., Hubacek, K., and Reed, M., 2009. Stakeholder Analysis and Social Network Analysis in Natural Resource Management. Society and Natural Resources, 22, 501-518.

Preston, B.L., Westaway, R.M., and Yuen, E.J., 2010. Climate adaptation planning in practice : an evaluation of adaptation plans from three developed nations.

Putnam, R.D., 1993. Social Capital and Institutional Sucess. Making Democracy Work, 162-185.

Putnam, R.D., 2000. Bowling alone : the collapse and revival of American community. New York (USA): Simon \& Schuster.

Ramieri et. al, 2015. Valoración de los impactos de actividades humanas y del cambio climático, detección de sitios clave y propuesta de medidas de adaptación - Informe del valoración de los impactos de actividades antrópicas y del cambio climático. Proyecto "Diseño de medidas. Mexico, D.F.

Ramieri et al., 2015. Diagnóstico de la situación actual del humedal. Proyecto "Diseño de medidas de adaptación para reducir la vulnerabilidad del sitio piloto del sistema lagunar Carmen-PajonalMachona, Tabasco, a los impactos generados por el cambio climático y por actividad. Mexico, D.F. 
Ridgeway, S., 2001. Monoculture, Monopoly, and the Mexican Revolution: Tomás Garrido Canabal and the Standard Fruit Company in Tabasco (1920-1935). Mexican Studies/Estudios Mexicanos, 17 (1), 143169.

Rotberg, F.J.Y., 2013. Social networks, brokers, and climate change adaptation: a Bangladeshi case. Journal of International Development, 25, 599-608.

Schmitt, E., Comoé, H., and Barjolle, D., 2013. Social Networks Analysis of the Ivorian Agricultural Sector Regarding Adaptation to Climate Change. Yearbook of Socioeconomics in Agriculture, 6 (1), 81-108.

Schneiderbauer, S., Calliari, E., Eidsvig, U., and Hagenlocher, M., 2017. The most recent view of vulnerability. In: K. Poljanšek, M. Marin Ferrer, T. De Groeve, and I. Clark, eds. Science for Disaster Risk Management 2017: knowing better and loosing less, . Luxembourg: Publications Office of the European Union, 68-82.

Scrivens, K. and Smith, C., 2013. Four Interpretations of Social Capital. Paris, France: OECD Publishing.

Smit, B. and Pilifosova, O., 2001. Adaptation to Climate Change in the Context of Sustainable Development and Equity. In: J.J. Mc-Carthy, O.F. Canzianni, N.A. Leary, D.J. Dokken, and K.S. White, eds. Climate Change 2001: Impacts, Adaptation, and Vulnerability - Contribution of Working Group II to the Third Assessment Report of the Intergovernmental Panel on Climate Change. Cambridge: Cambridge University Press, 877-912.

TABASCO, 2013. Ley de protección ambiental del estado de Tabasco.

Tudela, F., 1989. La Modernización forzada del trópico : el caso de Tabasco. 1st edition. Mexico: Centro de Estudios Demográficos y de Desarrollo Urbano, Colegio de México.

Tuleda, F., 1990. Recursos naturales y sociedad en el trópico húmedo tabasqueño. In: E. Leff, ed. Medio ambiente y desarrollo en México. Vol. I. Mexico: Centro de Investigaciones Interdisciplinarias en Humanidades, UNAM, 149-227.

UNEP, 2014. The Adaptation Gap Report 2014. Nairobi.

UNFCCC, 2015. Paris Agreement.

Varela-Ortega, C., Blanco-Gutiérrez, I., Esteve, P., Bharwani, S., Fronzek, S., and Downing, T.E., 2016. How can irrigated agriculture adapt to climate change? Insights from the Guadiana Basin in Spain. Regional Environmental Change, 16 (1), 59-70.

Vázquez, L.M., 2017. Implementation challenges of climate change adaptation initiatives in coastal lagoon communities in the Gulf of Mexico. Maritime Studies, 16 (14).

Wasserman, S. and Faust, K., 1994. Social network analysis : methods and applications. Cambridge, UK: Cambridge University Press.

Woodruff, S.C. and Stults, M., 2016. Numerous strategies but limited implementation guidance in US local adaptation plans. Nature Climate Change, 6 (August), 796-802. 
Woolcock, M., 2001. The place of social capital in understanding social and economic outcomes. Canadian Journal of Policy Research, 2 (1), 1-35. 